\title{
Nitric Oxide Measurement
}

National Cancer Institute

\section{Source}

National Cancer Institute. Nitric Oxide Measurement. NCI Thesaurus. Code C112360.

The determination of the amount of nitric oxide present in a sample. 